Başer, D. (2021). An investigation of self-efficacy and perceived benefit beliefs regarding distance education of preservice teachers as future implementers. Bolu Abant İzzet Baysal Üniversitesi Ë̆itim Fakültesi Dergisi, 21(4), 1145-1158. https://dx.doi.org/10.17240/aibuefd.2021..-955655

Makalenin Türü / Article Type Geliş Tarihi / Date Received Kabul Tarihi / Date Accepted Yayın Tarihi / Date Published
: Araștırma Makalesi / Researh Article

: 21.06.2021

$: 14.09 .2021$

: 15.12 .2021

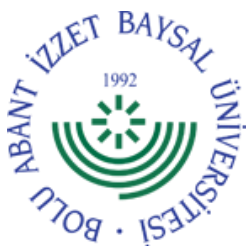

\title{
AN INVESTIGATION OF SELF-EFFICACY AND PERCEIVED BENEFIT BELIEFS REGARDING DISTANCE EDUCATION OF PRESERVICE TEACHERS AS FUTURE IMPLEMENTERS
}

\author{
Derya BAŞER ${ }^{1}$
}

\begin{abstract}
The current study aims to explore self-efficacy and perceived benefit beliefs of preservice teachers regarding distance education according to their experiences as future implementers of distance education from an undergraduate distance education course they received. A case study was employed including both quantitative and qualitative data collection methods. The participants of the current study were 143 preservice teachers who had completed a distance education course during their undergraduate program at a university in Turkey. Quantitative data were collected through two, five-point, Likert-type scales, with one that assessed self-efficacy towards distance education and one that assessed perceived benefit beliefs regarding distance education. Qualitative data were collected through an open-ended questionnaire. Descriptive statistics results from the scale data revealed that the mean scores for the constructs of self-efficacy and perceived benefit of distance education ranged from 3.66 to 4.07. Correlation analysis results indicated that the preservice teachers' self-efficacy towards distance education was significantly related to their perceived benefit from distance education, $r=.56, \mathrm{p}<.01$. The preservice teachers mentioned positive aspects of their distance education course under (1) Contribution of the course to the preservice teachers' knowledge and skills development for technology integration, (2) Contribution of the course to the preservice teachers' knowledge and skills development for designing effective distance education, (3) Positive features of the distance education course, and (4) Positive features of distance education in general. The preservice teachers stated negative aspects under (1) Issues related to common course components, and (2) Issues related to technology. The research results and implications are presented and discussed within this study.
\end{abstract}

Keywords: Distance education, teacher education, preservice teachers, self-efficacy, benefit belief

\section{GELECEKTEKİ UYGULAMACILAR OLARAK ÖĞRETMEN ADAYLARININ UZAKTAN EĞITIME YÖNELİK ÖZ YETERLİK VE YARAR ALGILARI ÜZERİNE BIR ARAŞTIRMA}

\section{öz}

$\mathrm{Bu}$ çalışma, uzaktan eğitimin gelecekteki uygulayıcıları olan öğretmen adaylarının, uzaktan eğitim dersine ilişkin deneyimleriyle birlikte öz yeterliklerini ve fayda inançlarını araștırmayı amaçlamaktadır. Bu çalıșmada hem nicel hem de nitel veri toplama yöntemlerini içeren bir vaka çalışması kullanılmıştır. Çalışmanın katılımcıları, Türkiye'deki bir üniversitede lisans programlarında uzaktan eğitim dersini tamamlayan, 143 öğretmen adayından oluşmaktadır. Nicel veriler uzaktan eğitime yönelik öz yeterlik ve algılanan fayda inançlarını değerlendiren iki beşli Likert tipi ölçek aracıllğıyla, nitel veriler açık uçlu anket aracılığıyla toplanmıştır. Ölçeklerin betimsel istatistik sonuçları, uzaktan eğitime yönelik öz yeterlik ve algılanan fayda bileşenlerinin ortalama puanlarının 3,66 ile 4,07 arasında değiştiğini ortaya koymuştur. Korelasyon analizi sonuçları, öğretmen adaylarının uzaktan eğitime yönelik öz yeterliklerinin algıladıkları fayda ile anlamlı düzeyde ilişkili olduğunu göstermiştir, $r=$ $.56, \mathrm{p}<.01$. Öğretmen adaylarının uzaktan eğitim dersi ile ilgili olumlu algıları dört başlık altında toplanmıştır: (1) Dersin öğretmen adaylarının teknoloji entegrasyonu için bilgi ve beceri gelişimine katkısı, (2) dersin öğretmen adaylarının etkili bir uzaktan eğitim tasarlayabilmeleri için bilgi ve beceri gelişimine katkısı, (3) dersin olumlu özellikleri ve (4) uzaktan eğitimin olumlu özellikleri. Öğretmen adayları dersin olumsuz yönlerini ise (1) ders bileşenleri ile ilgili sorunlar ve (2) teknolojiyle ilgili sorunlar hakkında belirtmişlerdir. Araştırma sonuçları ve çıkarımları makalede tartışılmaktadır.

Anahtar Kelimeler: Uzaktan eğitim, öğretmen eğitimi, öğretmen adayları, öz-yeterlik, yarar algısı

\footnotetext{
'Bolu Abant İzzet Baysal Üniversitesi, Eğitim Fakültesi, derya.yasar@gmail.com, (ㄴ) https://orcid.org/0000-0002-2006-8737
} 


\section{INTRODUCTION}

Recently, face-to-face education has been partially or completely replaced by distance education on a worldwide scale in an attempt to prevent the spread of the COVID-19 virus as a pandemic. Even if and when the COVID-19 pandemic is curtailed at some point in the future and we have the opportunity to return to face-to-face education, distance education will likely take on a wider and more important place in formal education when compared back to the pre-COVID era. Therefore, understanding distance education and its requirements is now more important than before in order that it may appropriately contribute to the quality of formal education on offer through benefitting from its affordances.

Distance education has been defined as "institution-based, formal education where the learning group is separated, and where interactive telecommunications systems are used to connect learners, resources, and instructors" (Schlosser \& Simonson, 2009, p. 1). Based on this definition, institutions should provide learners with digital platforms where they have the opportunity to access all the necessary resources, and to be able to interact with the resources, theirs peers, and their instructors via electronic media. With the change and diversification of technologies and learning resources in distance education, additional roles, or different at least, have been created for today's instructors, termed "online roles" (Berigel \& Çetin, 2020) which may be classified as: "pedagogic roles," "social roles," "managerial roles," and "technical roles" (Berge, 1995). As such, teacher training has become as essential key element in order for teachers (both preservice and inservice) to fulfill these various roles.

Self-efficacy, as in "how well one can execute courses of action required to deal with prospective situations" (Bandura, 1982, p. 122), is one of the key concepts on the road to achievement in online teaching platforms (Cho \& Shen, 2013; Kundu, 2020; Zimmerman, 2000) as it significantly affects human behavior (Bandura, 1982). Arpac1's (2017) study indicated that self-efficacy positively affects ease of use and therefore also attitude toward distance education. Another result of Arpacı's (2017) study was that perceived benefit (usefulness) was conceived as another important concept that can affect attitude toward distance education. Perceived benefit (usefulness) can be defined as "the degree to which a person believes that using a particular system would enhance his or her job performance" (Davis, 1989, p. 320). Y1ldiz and Erdem (2018) described self-efficacy and perceived benefit of instructors giving distance courses in undergraduate programs for distance education. The results of their study indicated high self-efficacy beliefs in both technology management and virtual classroom management, and low self-efficacy beliefs in learning management. In addition, they found high benefit beliefs in the economical nature of distance learning, but low benefit beliefs in the effectiveness of the learning products and the variety of learning experiences distance education offers.

Researchers have largely focused on improving the quality of distance learning at all levels of education, especially during the pandemic. Many studies have investigated the training of inservice teachers (Sahin-Topalcengiz \& Yildirim, 2020; Schreiber \& Jansz, 2020; Tekin, 2020) and preservice teachers' development through distance learning (Gurjar, 2020; Karakus et al., 2020; Sutiah et al., 2020). Whilst these studies have investigated both inservice and future (preservice) teachers as distance learners; however, they will predominantly be instructors of distance education themselves; therefore, their performances related to what are considered "new roles" is crucial to the success of any distance education they may offer. There have only been a few studies published that have investigated inservice or preservice teachers' qualifications for distance education. Marek et al. (2021) explored teachers' experiences regarding distance learning during the COVID-19 pandemic, and concluded that teachers were in need of instructional design training on distance learning. In another study, Arpac1 (2017) investigated key factors related to preservice IT teachers' attitudes and behavioral intentions toward distance education.

Although there has been an increase in the number of online and blended K-12 programs even prior to the pandemic, most teachers generally do not have the opportunities to learn about the appropriate use of online pedagogies and the current technologies employed within distance education as part of their undergraduate teacher education (Cooper et al., 2020). Today's teacher education programs should prepare future teachers for the appropriate design and delivery of distance education in order to provide tomorrow's teachers with the skills necessary for the conditions likely to develop following a return to "normality" after the pandemic (Rice \& Deschaine, 2020). Kanbul et al. (2020) advocated that distance education courses should be included as part of undergraduate preservice teacher training programs as teachers often felt they lacked the required competencies, lacking sufficient knowledge and skills to fulfill the requirements of a distance educator. In Turkey, a distance education course has been added to the new curriculum developed for Faculties of Education, which was implemented as from the 2018-2019 academic year. As an elective rather than compulsory course, all preservice teachers have the option to enroll to this course.

The current study aims to explore the self-efficacy beliefs and perceived benefit beliefs of preservice teachers regarding distance education, and to investigate their experiences about the elective Distance Education course on offer to preservice teachers in Turkey. Within this aim, the self-efficacy and perceived benefit levels of preservice teachers who completed the aforementioned course are described, and the relationship between the two variables 
is investigated. The preservice teachers' experiences within the Distance Education course are also presented so as to shed light on how to best design distance education courses in the future. For the purpose of the current study, answers to the following research questions were sought:

1- What is the level of self-efficacy belief of preservice teachers toward distance education following completion of a distance education course?

2- What is the level of perceived benefit beliefs of preservice teachers from distance education following completion of a distance education course?

3- Is there a relationship between the perceived self-efficacy and benefit beliefs of preservice teachers with regards to distance education?

4- What are the positive and negative design aspects of a distance education course according to preservice teachers?

\section{METHOD}

The current study was designed as a case study, employing both quantitative and qualitative data collection methods with the aim being to understand (Yin, 2014) preservice teachers' self-efficacy and perceived benefit towards distance education based on their experiences from a distance education course they completed during their undergraduate teacher education program.

\subsection{Participants}

The participants of the current study are 143 preservice teachers $(85.3 \%$ female, $14.7 \%$ male) who had each previously completed an elective "Distance Education" course as part of their undergraduate studies at a university in Turkey. The participants were from 11 different disciplines from within the Faculty of Education, and consisted of preservice teachers from the fields of Social Studies (10.5\%), English as a Foreign Language (10.5\%), Primary School (16.1\%), Science (11.9\%), Guidance (4.2\%), Mathematics (6.3\%), Visual Arts (6.3\%), Preschool (15.4\%), Music $(9.1 \%)$, Turkish (7.0\%), and Special Education (2.8\%). In terms of the participants' undergraduate level, the study was conducted with 28 sophomores and 115 juniors. All of the participants were considered to possess basic technological knowledge, and had also experienced distance education themselves as learners.

\subsection{Context}

The participants in the current study were all preservice teachers enrolled to an elective course on distance education, and each had joined the study on a voluntary basis at the end of the course semester. The distance education course was delivered remotely to the preservice teachers, who were from various different fields of education. Within the scope of the course, various topics regarding the theoretical knowledge that preservice teachers, as future teachers, should possess about distance education was presented each week. Following presentation of the relevant theory, the preservice teachers acquired practical experience of using various tools and software in accordance with the given topic such as how to manage learning, giving real-time feedback, promoting interaction, creating a digital board, developing asynchronous interactive videos, videoconferencing, assessment of learning, and various Web 2.0 tools that they could apply as appropriate to in their own discipline of teaching. Whilst teaching the course topics, the instructor utilized pedagogical strategies and tools taught through interactive tools in order to increase interactivity within the class. The preservice teachers were evaluated through performance-based homework assignments in which they developed interactive videos for asynchronous application, create instructional materials, and also designed a distance education lesson. The instructor applied group work so as to promote student-student interaction during their work on the assignments.

\subsection{Data collection and instruments}

Quantitative data were collected through two, five-point, Likert-type scales that assessed self-efficacy towards distance education and perceived benefit beliefs related to distance education. The online forms of the scales were offered to the participant preservice teachers who were each enrolled in the distance education course, and a total of 143 preservice teachers completed the scales at the end of the course semester.

Both the Self-Efficacy Scale and Perceived Benefit Scale were developed and validated by Yildiz and Erdem (2018). The Self-Efficacy Scale consists of three factors: "Learning management," "Technology management," and "Virtual class management." Exploratory factor analysis results of the Self-Efficacy Scale indicated high factor loading coefficients which ranged from .56 to .90 , whilst the Cronbach alpha coefficient for the three factors were each found to be higher than .78 (Y1ldiz, 2015). The authors also conducted exploratory factor analysis for the Perceived Benefit Scale and found three factors: "Effectiveness of learning products," "Variety of learning experiences," and "Low cost of the system." The loading coefficients for the three factors were found to vary from .51 to .89 , and the reliability coefficient for the three factors were each higher than .66 . 
Qualitative data for the study were collected through an open-ended questionnaire as part of the scales. The researcher required the participant preservice teachers to report on three positive and three negative aspects of the distance education course they had attended based on their own course experiences with two open-ended questions. The open-ended questionnaire was completed by 107 (74.8\%) of the 143 preservice teachers at the end of the course semester.

\subsection{Data analysis}

Descriptive statistics were utilized to present the preservice teachers' self-efficacy towards and perceived benefits from distance education for the quantitative data. Also, Pearson's product moment correlation was used as a bivariate correlation coefficient to investigate correlation between the two variables as the data were found to be normally distributed (Field, 2009). For the qualitative data, inductive analysis was applied through a coding system in which the researcher separated the collected data into units with codes, and then searched for patterns and topics among the data in order to create coding categories (Bogdan \& Biklen, 2007). The current study utilized methods triangulation (Lincoln \& Guba, 1985) as a trustworthiness technique by supporting the quantitative results with qualitative results.

\subsection{Ethics committee permit information}

In this study, all the rules specified to be followed within the scope of "Higher Education Institutions Scientific Research and Publication Ethics Directive" were complied with. None of the actions specified under the heading "Actions Contrary to Scientific Research and Publication Ethics", which is the second part of the directive, have been taken.

Ethical evaluation committee name: Bolu Abant Izzet Baysal University, Human Research Ethics Committee in Social Sciences

Date of ethical assessment decision: 15.11.2020

Ethical assessment document number number: 2020/260

\section{RESULTS}

\subsection{Preservice teachers' self-efficacy and perceived benefit beliefs regarding distance education}

Both the Self-Efficacy Scale and Perceived Benefit Scale were applied after the participant preservice teachers had completed the elective undergraduate course on Distance Education. The preservice teachers rated their selfefficacy $(\mathrm{M}=3.97, \mathrm{SD}=.75)$ towards distance education and their perceived benefit $(\mathrm{M}=3.70, \mathrm{SD}=.88)$ from distance education. The descriptive statistics results revealed that the mean scores for the constructs of distance education self-efficacy and perceived benefit from distance education ranged from 3.66 to 4.07 . Table 1 presents the participants' mean scores and standard deviations for the constructs of the two variables. The results show that the highest mean score in terms of self-efficacy was related to Technology Management, whilst for perceived benefit it was for Variety of Learning Experiences.

\section{Table 1.}

Descriptive Results of The Preservice Teachers' Self-Efficacy and Perceived Benefit Beliefs

\begin{tabular}{llll}
\hline Constructs & Variables & $\boldsymbol{M}$ & $\boldsymbol{S D}$ \\
\hline Self-efficacy & Learning management & 3.95 & .85 \\
& Technology management & 4.07 & .78 \\
Perceived benefit & Virtual class management & 3.82 & .92 \\
& Effectiveness of learning products & 3.66 & .95 \\
& Variety of learning experiences & 3.78 & .98 \\
& Low cost of system & 3.75 & .92 \\
\hline
\end{tabular}

Prior to conducting correlation analysis between the self-efficacy and perceived benefit scores, normality was checked through skewness and kurtosis values for the mean scores of distance education self-efficacy and perceived benefit. As all of the values were found to be between -1.5 and +1.5 (Tabachnick \& Fidell, 2013), normality assumption of Pearson's product-moment correlation was maintained. After assuming normality, the researcher decided to utilize Pearson's product-moment for the correlation analysis as the sample size exceeded 100 (Warner, 2021). Then, bivariate correlation was applied to calculate Pearson's correlation coefficient between the two variables. The results indicated that the preservice teachers' self-efficacy towards distance education was significantly related to their perceived benefit from distance education, $\mathrm{r}=.56, \mathrm{p}<.01$. A related effect size, coefficient of determination ( $\mathrm{r} 2$ ), was also calculated as .3136. This coefficient indicated that $31.36 \%$ of variability 
in the preservice teachers' self-efficacy was accounted from their perceived benefit beliefs, which represents a large effect size according to Cohen's d (1988).

\subsection{Positive and negative aspects of the distance education course}

The preservice teachers were asked to identify three positive and three negative aspects about the course they received on distance education in order to explore those aspects that might be associated with their high mean scores. The following sections provide an overview of the preservice teachers' positive and negative opinions about their distance education course.

\subsubsection{Positive aspects of the distance education course}

The qualitative analysis revealed four themes of positive results: (1) Contribution of the course to the preservice teachers' knowledge and skills development for technology integration; (2) Contribution of the course to the preservice teachers' knowledge and skills development for designing an effective distance education; (3) Positive features of the course; and (4) Positive features of distance education in general.

Under the first theme, the preservice teachers considered that the course they had attended on distance education helped them to develop their knowledge and skills in using technology for teaching purposes. Overall, 47 of the preservice teachers stated that they had improved their technological knowledge and skills in general or with specific tools/programs such as Web 2.0 and Camtasia. Also, 41 of the preservice teachers thought that their knowledge and skills for integrating technology into teaching had developed with the help of the course. The following participants' excerpts demonstrate the thoughts of some of the participants with regards to the development of their technology integration knowledge and skills:

I am attracted to technological teaching tools, and in learning about their diversity. I also realized the benefit of this diversity in our community service course. I was able to use tools that not everyone knows about. This was great. [P37]

While thinking about how to use technology in the preschool environment, I learned that there are many easy programs that I can use, thanks to our [DE] instructor. [P15]

In addition to the knowledge and skills of using technology for teaching purposes, the participant preservice teachers expressed that they had learned how to design distance education more effectively. The comments made included having learned about teaching strategies (19 preservice teachers), appropriate tools (10 preservice teachers), and materials development (eight preservice teachers) for the purposes of delivering distance education. The following participants' excerpts indicate some of the opinions put forth in relation to the contribution of the Distance Education course to their knowledge and skills for producing effective distance education designs in the future:

Learning materials that we can use for distance education in the future. [P8]

I learned how various learning programs are used in distance education. Every week, we learned about the different applications used in various ways in the distance education process. [P83]

I developed my knowledge about favorable approaches that I could use to support children's participation in my lessons. I learned how to be prepared for situations that could be changeable. [P103]

Being aware that active learning can also be achieved remotely if we want it to. [P25]

The preservice teachers also mentioned the positive features of the Distance Education course they had attended remotely. Of the respondents, 20 of the preservice teachers asserted that the course provided them with an interactive learning environment, whilst four mentioned rich and clear content, eight talked about homework assignments that helped to support learning, and 39 of the participant preservice teachers mentioned an efficient learning environment with effective pedagogical and classroom management strategies. A selection of the preservice teachers' relevant statements are presented as follows:

With the distance education course, I had more opportunity to communicate and socialize with my classmates. [P45]

I was happy doing the homework, which really contributed something for me as I felt like I was actually learning something. [P40]

I can also say that watching the lecture on the screen with visuals and presentations, not just talking, helped to increase my attention span even more. [P44] 
The topics taught did not remain abstract. After each topic [was taught], the necessary applications were then demonstrated, which was very useful to be honest. I was very pleased and did not have any difficulties as the topics were areas that appealed to me in general. [P23]

The preservice teachers also listed the positive features of distance education as some of the positive aspects of the course they had attended on distance education. Six of the preservice teachers indicated that distance education was easy to use, whilst 14 mentioned that it saved time and cost, 13 said that distance education was comfortable to use, and 13 stated that it was flexible in terms of time and place and that it provided comfortable class sessions. Finally, six of the preservice teachers said that distance education provided learning opportunities beyond face-toface learning such as developing self-regulated learning, providing a variety of learning opportunities, and in reaching more students. The following statements demonstrate some of the participant preservice teachers' perceptions about the positive features of distance education:

The system we used is easily to hand and we can access it. [P50]

It is an effective, time-saving format. [P80]

[It is] independent from place and [it provides] for flexibility for homework time. [P60]

In my opinion, one of the positive aspects of the distance education course is that it provides

the opportunity for us to reach more students. [P86]

\subsubsection{Negative aspects of the distance education course}

When the researcher asked the participant preservice teachers about the negative aspects of their Distance Education course, 14 of them stated that they experienced no negative aspects. When the other participants' answers were analyzed, two themes emerged: (1) Issues related to common course components; and, (2) Issues related to technology.

Under the first issue relating to common course components, six of the preservice teachers found difficulty in understanding some of the concepts, whilst one stated having already known most of the tools that were presented. Moreover, the preservice guidance counselors expressed that that some of the content was inappropriate for their field. In total, 12 of the preservice teachers reported issues related to interaction as another issue with the course, whilst some mentioned communication problems in general, and a few pointed to inadequacies in terms of studentteacher interaction. Of the preservice teachers, 10 also listed issues that they experienced during live class sessions. Some of them were unhappy about opening their web cameras, having class attendance registered, and about noise levels during the live class sessions. Related to the class assignments, as another common course component, 31 of the preservice teachers complained about the difficulty level of the assignments, the heavy workload that the assignments involved, and about collaborative group working for the assignments. Finally, seven of the participants had experienced problems with the timing of the live class sessions in terms of the duration (length) and time that the classes had been scheduled. A selection of the participant preservice teachers' statements regarding their negative opinions about the common components of the course are as follows:

There were not many tools available for my field of Psychological Counseling and Guidance. I had difficulty adapting some of the course assignments to my field. [P69]

I am hesitant to mention in the lesson when there is a topic I don't fully understand. [P106]

I don't like to open my camera during distance education lessons. It was difficult to get used to working from a distance. [P32]

I had difficulty with the group assignments and in forming a group because there were students from different branches of teaching. After forming the group, there were communication problems in reaching each other, and with talking about the group assignment. Therefore, it could be better to just be supporting one peer or in groups of two at most, rather than [four-person] group assignments. [P11]

The preservice teachers' experiences regarding technology-related issues emerged as four categories: (1) Distance education over face-to-face education; (2) Insufficient digital equipment; (3) Technical problems; and (4) Tools or software used within the course. Under the first category of technology-related issues, 42 of the preservice teachers considered distance education to be more inefficient than face-to-face education overall, whilst some specified inefficiencies as in communicating, actively engaging in learning, being motivated, and maintaining attention. Furthermore, some of the preservice teachers stated that they could not attend the live classes, whilst some considered distance education to be more tiring in comparison to face-to-face education. On the issue of insufficient digital equipment, 20 of the preservice teachers mentioned having limited technological opportunities in general, whilst some specifically noted that a lack of computer equipment was a problem for them. Also, one of the preservice teachers mentioned that their inability to use an IT classroom negatively affected their performance 
on the course. As the third technology-related issue, 44 of the preservice teachers listed technical problems that they encountered during distance education as: infrastructure, electricity supply, the Internet, audio, failure of videoconferencing software, and other technical problems. Finally, seven of the preservice teachers noted that some of the software or tools used within the scope of the Distance Education course content were difficult to use. Some experienced difficulties in learning by applying the programs during live class sessions, whilst some evaluated the English language interface of the tools as a negative issue [Note: the participants of the current study were native Turkish speakers]. The following are excerpts that indicate some of the preservice teachers' opinions regarding technology-related issues:

Education received in the home environment is not as effective as in the classroom. Although not as efficient as face-to-face education, I think it [the distance education course] was given in the most efficient way. [P28]

Since my computer did not work properly, I could not find the opportunity to use some of the applications specified during the distance education classes. [P45]

I had problems with the Internet connection or connection problems caused by the [learning management] system. [P97]

While lecturing, I could not access the sites myself that you [the instructor] entered even though I watched you, which made it difficult for me to learn how to use the site. [P79]

\section{DISCUSSION AND IMPLICATIONS}

The preservice teachers' relatively high mean scores for their self-efficacy toward distance education revealed that they felt competent as future distance educators, and specifically in the learning, technology, and the virtual classroom management aspects of distance education. Although not as high as their self-efficacy, their benefit perception mean scores were found to be quite close to good. That is, their perceived benefit beliefs on the effectiveness of the learning products, variety of the learning experiences, and low cost of the system were much higher than simply a moderate level. However, it was noticeable that these results contradicted some other studies that have been conducted with preservice teachers. In a study conducted with 173 preservice teachers, Karatepe et al. (2020) found that preservice teachers felt insufficient as distance educators, that they had a negative attitude towards distance education based on their experience from higher education courses, and that they did not want to provide distance education in the future. Another study examined 92 preservice Turkish teachers' knowledge and skills to use distance education, which reported that $50 \%$ of the participants stated having low-level knowledge and skills (Karakuş et al., 2020). This contradiction probably stems from the Distance Education course that the participating preservice teachers completed in their undergraduate programs in the current study and the elective nature of the course might have contributed to the high scores of the preservice teachers.

As there has been limited research conducted with preservice teachers as distant educators rather than distant learners, other studies conducted with inservice teachers were also examined. According to the results of a study by Üstün et al. (2020), which was conducted with 994 teachers in Turkey, their readiness, self-confidence, and attitudes towards e-learning were found to be at a moderate level. In another research involving 242 teachers, Karaca et al. (2021) found that the participating teachers indicated a moderate level of perceived benefit from distance education. When teachers working in primary schools were investigated with regards to distance education, their attitudes concerning the advantages of distance education, its limitations, and also about distance education in general, were found to be of an average level (Ülkü, 2018). In a study conducted with early career teachers in Germany, König et al. (2020) found that the rate of managing challenges during online teaching and online assessment was not high. Bakioğlu and Çevik (2020) revealed that Science teachers felt incompetent regarding distance education from the findings of their study. Also, lack of knowledge regarding the preparation of distance education content was considered to be one of the most challenging factors for teachers in a study published by Karadeniz and Zabc1 (2020). Finally, according to Rice and Deschaine (2020), teachers should be specifically trained with regards to distance education as part of their undergraduate teacher training program so as to promote their competencies as future distance educators.

In addition to descriptive results of the quantitative data, correlation analysis between the preservice teachers' selfefficacy and perceived benefit scores indicated a positive significant correlation which support the technology acceptance model. The model, which focuses on what influences behavioral intention to use a certain technology, claims that perceived usefulness (benefit) is influenced by external variables (Davis et al., 1989) including selfefficacy (Teo et al., 2009), and that they indirectly influence behavioral intention to use that technology.

According to the descriptive results of the scales applied following completion of the distance education course, the self-efficacy and perceived benefit level of the participant future teachers was found to be quite high when compared to the results of other relevant studies in the literature. With the belief that the Distance Education course 
might contribute to their high level of perception, the researcher thought that exploring the successful and unsuccessful aspects of the course may shed light on how best to design distance education courses for undergraduate programs in the future.

Analysis of the qualitative data collected through open-ended questionnaires held with the preservice teachers revealed that they valued the development of their knowledge and skills not only for the purposes of technology integration, but also in terms of designing distance education. Experts in a study by Kanbul et al. (2020) supported this idea, claiming that an effective distance education system can be realized through undergraduate distance education courses in which preservice teachers gain the required theoretical and practitioner knowledge regarding distance education. Additionally, the preservice teachers in the current study found their course to be successful due to features of the course such as its level of interaction, the course content, homework assignments, and the efficiency of the learning environment. Parker (2020) described interaction as a critically essential component of distance education; therefore, instructors should ensure that the design of distance education courses include an appropriate degree of interaction. Also, course instructors are considered responsible for the provision of course content that meets the target students' needs and expectations, which is a traditionally accepted concept for most educational courses (Willis, 1994). Furthermore, distance education in which homework assignments are integrated are seen to positively affect student achievement, as well the teaching and learning process itself in general (Karabatak et al., 2020). Learning environments may, therefore, be effectively designed when organized in accordance with the nature of a distance learning program (Kearsley \& Lynch, 1996) by ensuring that appropriate pedagogical and classroom management strategies are employed to good effect.

The preservice teachers in the current study also listed what they considered to be beneficial features of distance education in terms of the course they attended. These benefits included: ease of use, which might then promote motivation (Fidalgo \& Tormann, 2020); time-saving (Fidalgo \& Tormann, 2020); cost-effectiveness (Moore \& Kearsley, 2012); independence of time and place (Fidalgo \& Tormann, 2020; Kanbul et al., 2020); and, provision of learning opportunities beyond face-to-face instruction (King et al., 2001). These qualitative results may be considered useful to the design of future distance education courses aimed at preservice teachers.

The preservice teachers also stated what they saw as negative aspects of the distance education course they attended as having stemmed from technology-based issues, or related to components of the course. Similar technologyrelated issues were also mentioned by preservice teachers in the study of Alan et al. (2020). Although considered independent from the course design, such technology-related issues can be minimized whilst designing the learning environment. In terms of course components, according to the preservice counseling teachers in the current study, course content should be prepared in such a way so as to cover all preservice teachers taking the course. The study's findings revealed that distance education courses should be appropriately designed in order to maximize interaction, as suggested by Muzammil et al. (2020). In terms of live class sessions, some of the preservice teachers in the current study appeared comfortable to, for example, open their web cameras during classes, and also for class attendance to be taken, whilst some others complained about these issues. Therefore, instructors may wish to decide on these two issues together with those attending their courses, or by at least considering the conditions in play pertinent to the preservice teachers enrolled to their courses. The majority of the complaints made by the participant preservice teachers based on the course components were related to the students' assignments. On the other hand, some of the preservice teachers stated that assignments enabled them to learn better, whilst others found the assignments too difficult to complete, heavy going, or problematic because of group working issues. In future courses, preservice teachers could be provided with the opportunity to choose their assignments so as to increase student course satisfaction (MacNaul et al., 2021). Finally, live class sessions could be kept shorter by providing more breaks, as a few of the preservice teachers in the current study found the class time was too long for their liking.

\section{CONCLUSION}

The preservice teachers who participated in the current study first completed a distance education course, following which they rated their self-efficacy towards distance education and also their perceived benefit from distance education as being quite high. Also, positive aspects of the distance education course, according to the preservice teachers, support the high levels of self-efficacy and perceived benefit scores. The contribution of the course to the preservice teachers' knowledge, the way in which the distance education course was conducted, and the general features of distance education emerged as themes for the positive aspects of the course, which correspond to both the reported high level of self-efficacy and also their perceived benefit from distance education coming close to high. On the other hand, negative aspects indicated that the distance education course design still required further development in order that the preservice teachers would be more ready to become distance educators themselves having achieved very high scores in future iterations of such a course. 


\section{LIMITATIONS AND FURTHER RESEARCH}

The preservice teachers in the current study rated their own self-efficacy towards distance education, and also selfassessed their perceived benefit from distance education as being quite high following completion of their undergraduate course on distance education. As no pretest was applied in the current study, the research offers no evidence that points to the achieved high mean scores being related to the course itself; however, the study did shed light on the importance of distance education courses as a means to training preservice teachers as implementers of distance education in the future. Further research could therefore investigate the effect of such a distance course on preservice teachers' self-efficacy levels and also their perceived beliefs regarding course design. 


\section{REFERENCES}

Alan, Y., Biçer, N., \& Can, F. (2020). Perspectives of pre-service teachers on distance education: COVID-19 process. Revista Argentina de Clínica Psicológica, 29(5), 1972-1984. https://www.revistaclinicapsicologica.com/issue.php?volume=2\&issue=2\&page=9

Arpac1, İ. (2017). The role of self-efficacy in predicting use of distance education tools and learning management systems. Turkish Online Journal of Distance Education, 18(1), 52-62. https://doi.org/10.17718/tojde.285715

Bakioğlu, B. \& Çevik, M. (2020). COVID-19 pandemisi sürecinde fen bilimleri öğretmenlerinin uzaktan eğitime ilişkin görüşleri. Turkish Studies, 15(4), 109-129. https://dx.doi.org/10.7827/TurkishStudies.43502

Bandura, A. (1982). Self-efficacy mechanism in human agency. American Psychologist, 37(2), 122-147. https://doi.org/10.1037/0003-066X.37.2.122

Berge, Z. L. (1995). Facilitating computer conferencing: Recommendations from the field. Educational Technology, 35(1), 22-30.

Berigel, M. \& Çetin, İ. (2020). Açık ve uzaktan öğretimde öğreten ve öğrenen rolleri [Roles of teachers and learners in open and distance education]. In E. Tekinarslan \& M. D. Gürer (Ed.), Açık ve uzaktan ögrenme [Open and distance learning] (pp. 125-144). Pegem Akademi. https://doi.org/10.14527/9786052412411.07

Bogdan, R. C., \& Biklen, S. K. (2007). Qualitative research for education (5th ed.). Pearson Education.

Cho, M.-H., \& Shen, D. (2013). Self-regulation in online learning. Distance Education, 34(3), $290-301$. https://doi.org/10.1080/01587919.2013.835770

Cohen, J. (1988). Statistical power analysis for the behavioral sciences (2nd ed.). Academic Press.

Cooper, R., Warren, L., Hogan-Chapman, A., \& Mills, L. (2020). Pre-service teachers and their self-efficacy toward online teaching. SRATE Journal, 29(2), 1-7. http://www.srate.org/JournalEditions/Volume292/PDF/Cooper,\%20et\%20al.\%20Pre-Service\%20Teachers.pdf

Davis, F. D. (1989). Perceived usefulness, perceived ease of use, and user acceptance of information technology. MIS Quarterly, 13(3), 319-340. https://doi.org/10.2307/249008

Davis, F. D., Bagozzi, R. P., \& Warshaw, P. R. (1989). User acceptance of computer technology: A comparison of two theoretical models. Management Science, 35(8), 982-1003. https://doi.org/10.1287/mnsc.35.8.982

Fidalgo, P., \& Tormann, J. (2020). Students' perceptions on distance education: A multinational study. International Journal of Educational Technology in Higher Education, 17(1), 1-18. https://doi.org/10.1186/s41239-020-00194-2

Field, A. (2009). Discovering statistics using SPSS: Introducing statistical method (3rd ed.). Sage.

Gurjar, N. (2020). Leveraging social networks for authentic learning in distance learning teacher education. Tech Trends, 64, 666-667. https://doi.org/10.1007/s11528-020-00510-7

Kanbul, S., Zaitseva, N., Ikonnikov, A., Kalugina, O., Savina, T., \& Evgrafova, O. (2020). Determining expert opinions of the faculty of education on the development of distance learning course. International Journal of Emerging Technologies in Learning (iJET), 15(23), 52-62. https://doi.org/10.3991/ijet.v15i23.18783

Karabatak, S., Alanoğlu, M., \& Karabatak, M. (2020, June 1-2). Effects of homework supported distance education on academic satisfaction, academic achievement, and attitude towards distance education [Paper presentation]. International Symposium on Digital Forensics and Security (ISDFS), Online. https://doi.org/10.1109/ISDFS49300.2020.9116372

Karaca, İ., Karaca, N., Karamustafaoğlu, N. \& Özcan, M. (2021). Öğretmenlerin uzaktan eğitimin yararına ilişkin algılarının atıf incelenmesi. Humanistic Perspective, 3(1), 209-224. https://doi.org/10.47793/hp.844113

Karadeniz, G. \& Zabcı, N. (2020). Pandemi döneminde uzaktan eğitim veren öğretmenlerin çalışma koşulları ve algıladıkları stres ile psikolojik iyi oluşları arasındaki ilişki [The effects of teachers' experiences during the pandemic period, their well-being, stress levels and adaptation to distance education]. MSGSÜ Sosyal Bilimler Dergisi, 2(22), 301-314.

Karakuş, N., Ucuzsatar, N., Karacaoğlu, M. Ö., Esendemir, N. \& Bayraktar, D. (2020). Türkçe öğretmeni adaylarının uzaktan eğitime yönelik görüşleri [Turkish teacher candidates' views on distance education]. Rumeli Dil ve Edebiyat Araştırmalart Dergisi, 19, 220-241. https://doi.org/10.29000/rumelide.752297

Karatepe, F., Küçükgençay, N. \& Peker, B. (2020). Öğretmen adayları senkron uzaktan eğitime nasıl bakıyor? Bir anket çalışması [What are the perspectives of teacher candidates on synchronous distance education?: A survey study]. Journal of Social and Humanities Sciences Research, 7(53), 1262-1274. http://dx.doi.org/10.26450/jshsr.1868

Kearsley, G., \& Lynch, W. (1996). Structural issues in distance education. Journal of Education for Business, 71(4), 191-195. https://doi.org/10.1080/08832323.1996.10116783 
King, F. B., Young, M. F., Drivere-Richmond, K., \& Schrader, P. G. (2001). Defining distance learning and distance education. AACE Review (Formerly AACE Journal), 9(1), 1-14.

König, J., Jäger-Biela, D. J., \& Glutsch, N. (2020). Adapting to online teaching during COVID-19 school closure: Teacher education and teacher competence effects among early career teachers in Germany. European Journal of Teacher Education, 43(4), 608-622. https://doi.org/10.1080/02619768.2020.1809650

Kundu, A. (2020). Toward a framework for strengthening participants' self-efficacy in online education. Asian Association of Open Universities Journal, 15(3), 351-370. https://doi.org/10.1108/AAOUJ-06-20200039

Lincoln, Y. S., \& Guba, E. G. (1985). Naturalistic inquiry. Sage.

MacNaul, H., Garcia, R., Cividini-Motta, C., \& Thacker, I. (2021). Effect of assignment choice on student academic performance in an online class. Behavior Analysis in Practice. Advance online publication. https://doi.org/10.1007/s40617-021-00566-8

Marek, M. W., Chew, C. S., \& Wu, W. V. (2021). Teacher experiences in converting classes to distance learning in the COVID-19 pandemic. International Journal of Distance Education Technologies, 19(1), 40-60. https://doi.org/10.4018/ijdet.20210101.oa3

Moore, M., \& Kearsley, G. (2012). Distance education: A systems view of online learning (3rd ed.). Wadsworth.

Muzammil, M., Sutawijaya, A., \& Harsas1, M. (2020). Investigating student satisfaction in online learning: The role of student interaction and engagement in distance learning university. Turkish Online Journal of Distance Education, 21, 88-96. https://doi.org/10.17718/tojde.770928

Parker, A. (2020). Interaction in distance education: The critical conversation. AACE Review (Formerly AACE Journal), 13-17. https://www.learntechlib.org/primary/p/8117/

Rice, M. F., \& Deschaine, M. E. (2020). Orienting toward teacher education for online environments for all students. The Education Forum, 84(2), 114-125. https://doi.org/10.1080/00131725.2020.1702747

Sahin-Topalcengiz, E., \& Yildirim, B. (2020). Teachers' opinions about distance web 2.0 tools training and teachers' in-class web 2.0 practices. Journal of Turkish Science Education, 17(4), 561-577. http://www.tused.org/index.php/tused/article/view/1247

Schlosser, L. A., \& Simonson, M. (2009). Distance education: Definition and glossary of terms (3rd ed.). Information Age.

Schreiber, B. R., \& Jansz, M. (2020). Reducing distance through online international collaboration. ELT Journal, 74(1), 63-72. https://doi.org/10.1093/elt/ccz045

Sutiah, S., Slamet, S., Shafqat, A., \& Supriyono, S. (2020). Implementation of distance learning during the COVID-19 pandemic in faculty of education and teacher training. Cypriot Journal of Educational Sciences, 15(5), 1204-1214. https://doi.org/10.18844/cjes.v15i5.5151

Tabachnick, B. G., \& Fidell, L. S. (2013). Using multivariate statistics (6th ed.). Pearson.

Tekin, O. (2020). Uzaktan eğitim kullanılan hizmet içi eğitim programlarına yönelik öğretmen görüşlerinin incelenmesi [Investigation of teachers' views on distance learning in-service training programs]. Eğitimde Kuram ve Uygulama, 16(1), 20-35. https://doi.org/10.17244/eku.643224

Teo, T., Lee, C. B., Chai, C. S., \& Wong, S. L. (2009). Assessing the intention to use technology among preservice teachers in Singapore and Malaysia: A multigroup invariance analysis of the technology acceptance model (TAM). Computers \& Education, 53(3), 1000-1009. https://doi.org/10.1016/j.compedu.2009.05.017

Ülkü, S. (2018). İlkokullarda görev yapan ögretmenlerin uzaktan eğitime yönelik tutumları [Attitudes of teachers working in primary schools towards distance education] [Master's thesis, Bolu Abant İzzet Baysal University].

https://tez.yok.gov.tr/UlusalTezMerkezi/tezDetay.jsp?id=UB9xMtTbm9TFHzmmzeyZWw\&no=3tW bKIhiPRgR5CiddBET1w

Üstün, A. B., Yılmaz, F. G. K. \& Yılmaz, R. (2020). Öğretmenler e-öğrenmeye hazır mı? Öğretmenlerin eöğrenmeye yönelik hazır bulunuşluklarının incelenmesi üzerine bir araştırma [Are teachers ready for elearning? A study on exploring e-learning readiness of teachers]. Ahmet Keleşoğlu Eğitim Fakültesi Dergisi, 2(1), 52-67. https://acikerisim.bartin.edu.tr/bitstream/handle/11772/6463/eogrenme\%20hazirbulunusluk.pdf?sequence $=1 \&$ is Allowed $=\mathrm{y}$

Warner, R. M. (2021). Applied statistics I: Basic bivariate techniques (3rd ed.). Sage.

Willis, B. (1994). Distance education: Strategies and tools. Educational Technology Publications.

Yıldız, M. (2015). Uzaktan ĕgitim programlarında ders veren ögretim elemanlarının uzaktan eğitime yönelik bilgi, inanç ve uygulamaları arasındaki ilişkiler [Relationships between the knowledge, beliefs and practices of the instructors who teach in distance education programs] [Unpublished master's thesis]. Hacettepe University.

Yıldız, M., \& Erdem, M. (2018). An investigation on instructors' knowledge, belief and practices towards distance education. Malaysian Online Journal of Educational Technology, 6(2), 1-20. https://doi.org/10.17220/mojet.2018.04.001 
Yin, R. K. (2014). Case study research: Design and methods (applied social research methods). Sage. Zimmerman, B. J. (2000). Self-efficacy: An essential motive to learn. Contemporary Educational Psychology, 25(1), 82-91. https://doi.org/10.1006/ceps.1999.1016 


\section{GENIŞLETILMIŞ ÖZET}

\section{GİRIŞ}

Son zamanlarda, COVID-19 virüsünün yayılmasını önlemek amacıyla, dünya çapında yüz yüze eğitim yerini kısmen veya tamamen uzaktan eğitime bırakmıştır. COVID-19 salgını gelecekte kontrol altına alınabildiğinde ve tamamen yüz yüze eğitime dönme firsatına sahip olunduğunda bile, uzaktan eğitim pandemi öncesi döneme kıyasla örgün eğitimde daha geniş ve daha önemli bir yer edinecektir. Bu nedenle uzaktan eğitimin avantajlarından yararlanarak sunulan örgün eğitimin kalitesine en uygun şekilde katkıda bulunabilmek için uzaktan eğitimi ve gereksinimlerini anlamak çok daha önem arz etmektedir.

Özellikle pandemi süreci başladıktan sonra yapılan araştırmalar, büyük ölçüde eğitimin tüm seviyelerinde uzaktan eğitimin kalitesini artırmaya odaklanmıştır. Birçok çalışma, öğretmenlerin (Schreiber \& Jansz, 2020; ŞahinTopalcengiz \& Yıldırım, 2020; Tekin, 2020) ve aday öğretmenlerin uzaktan eğitim yoluyla gelişimlerini (Gurjar, 2020; Karakus vd., 2020; Sutiah vd., 2020) araştırmıştır. Bu çalışmalarda öğretmen ve öğretmen adayları öğrenen rolünde bulunmaktadır ancak uzaktan eğitim yoluyla öğretecek kişiler olarak öğretmen ve öğretmen adaylarının uzaktan eğitimin getirdiği "yeni roller" ile ilgili performansları, sunabilecekleri uzaktan eğitimin başarısı için çok önemlidir. Öğretmenlerin ya da aday öğretmenlerin, uzaktan eğitim için niteliklerini araştıran yalnızca birkaç çalışma yayınlanmıştır. Marek vd. (2021), COVID-19 salgını sırasında öğretmenlerin uzaktan eğitimle ilgili deneyimlerini araştırmış ve öğretmenlerin uzaktan eğitim konusunda öğretim tasarımı eğitimine ihtiyaç duydukları sonucuna varmıştır. Başka bir çalışmada, Arpacı (2017), aday bilişim teknolojileri öğretmenlerinin uzaktan eğitime yönelik tutumları ve davranışsal niyetleri ile ilgili temel faktörleri araştırmıştır.

Pandemi öncesinde bile çevrimiçi ve harmanlanmış K-12 programlarının sayısında bir artış olmasına rağmen, çoğu öğretmen genellikle lisans öğretmenliği eğitiminin bir parçası olarak çevrimiçi pedagojilerin uygun kullanımı ve uzaktan eğitim içinde kullanılan güncel teknolojiler hakkında bilgi edinme firsatına sahip değildir (Cooper vd., 2020). Bugünün öğretmen eğitim programları, yarının öğretmenlerine pandemi sonrası "normale" geri döndükten sonra gelişmesi muhtemel koşullar için gerekli becerileri sağlamak amaciyla gelecekteki öğretmenleri uygun tasarım ve uzaktan eğitimin teslimine hazırlamalıdır (Rice \& Deschaine, 2020). Kanbul vd. (2020), öğretmenlerin bir uzaktan eğitimcinin gereksinimlerini karşılamak için yeterli bilgi ve beceriden yoksun olduklarını hissettikleri araştırma sonucuna dayanarak uzaktan eğitim derslerinin öğretmen yetiştirme programlarının bir parçası olarak dahil edilmesi gerektiğini savunmaktadır. Türkiye'de, 2018-2019 eğitim-öğretim yılından itibaren uygulanan eğitim fakülteleri için geliştirilen yeni müfredata uzaktan eğitim dersi eklenmiştir. Her alandan aday öğretmenler, seçmeli ders olarak bu derse kaydolma hakkına sahiptir.

$\mathrm{Bu}$ çalışma, aday öğretmenlerin uzaktan eğitimle ilgili öz yeterlik inançlarını ve algılanan fayda inançlarını araştırmayı ve uzaktan eğitim dersi hakkındaki deneyimlerini keşfetmeyi amaçlamaktadır. Bu amaç çerçevesinde, uzaktan eğitim dersini tamamlayan aday öğretmenlerin öz yeterliği ve algılanan fayda düzeyleri ve iki değişken arasındaki ilişki araştırılmıştır. Aday öğretmenlerin, uzaktan eğitim dersi kapsamında edindikleri deneyimlerin keşfedilmesi ile uzaktan eğitim derslerinin gelecekte en iyi şekilde nasıl tasarlanabileceğine 1şık tutması planlanmaktadır. Bu çalışmanın amacı doğrultusunda aşağıdaki araştırma sorularına yanıt aranmıştır:

1- Uzaktan eğitim dersinin tamamlanmasının ardından aday öğretmenlerin uzaktan eğitime yönelik öz yeterlik düzeyi nedir?

2- Uzaktan eğitim dersinin tamamlanmasının ardından aday öğretmenlerin uzaktan eğitime yönelik algılanan fayda inançlarının düzeyi nedir?

3- Aday öğretmenlerin uzaktan eğitimle ilgili algılanan öz yeterlik ve algılanan fayda inançları arasında bir ilişki var midır?

4- Aday öğretmenlere göre uzaktan eğitim dersinin olumlu ve olumsuz tasarım yönleri nelerdir?

\section{YÖNTEM}

$\mathrm{Bu}$ çalışma, aday öğretmenlerin lisans programları kapsamında aldıkları uzaktan eğitim dersini tamamlamalarının ardından, uzaktan eğitime yönelik öz yeterlik ve yarar algılarını anlamak amacıyla hem nicel hem de nitel veri toplama yöntemlerini kullanan bir vaka çalışması olarak tasarlanmıştır. Çalışmaya, Türkiye'deki bir üniversitenin eğitim fakültesinde bulunan 11 farklı disiplinden 143 aday öğretmen (\%85,3 kadın, \%14,7 erkek) katılmıştır. Nicel veriler, uzaktan eğitime yönelik öz yeterlik ve yarar algısı inançlarını ölçen beşli Likert tipi ölçekler (Yıldız \& Erdem, 2018) aracılığıyla toplanmıştır. Çalışmanın nitel verileri, nicel verilerin toplandığı 143 aday öğretmenden 107 'sinin doldurduğu açık-uçlu anket yoluyla elde edilmiştir. Nicel verilerin analizi için betimsel istatistikler ve Pearson Momentler Çarpımı Korelasyonu kullanılırken, nitel veriler için kodlar birimlere ayrıldıktan sonra kategoriler oluşturularak veriler arasında desenlerin araştırıldığı bir kodlama sistemi olan endüktif analiz yöntemi uygulanmıştır (Bogdan \& Biklen, 2007). 


\section{BULGULAR, TARTIŞMA VE SONUÇ}

Katılımcı aday öğretmenler, uzaktan eğitim seçmeli lisans dersini tamamladıktan sonra uzaktan eğitime yönelik öz yeterliklerini $(\mathrm{M}=3.97, \mathrm{SD}=.75)$ ve algılanan fayda inançlarını $(\mathrm{M}=3.70, \mathrm{SD}=.88)$ derecelendirmiştir. Açıklayıcı istatistik sonuçları, uzaktan eğitime yönelik öz yeterlik ve algılanan fayda inançlarına ilişkin ortalama puanların 3,66 ile 4,07 arasında değiştiğini ortaya koymuştur. Bulguların analizinin sonraki aşamasında, iki değişken arasındaki korelasyon katsayısını hesaplamak için Pearson korelasyon analizi yapılmıştır. Sonuçlar, aday öğretmenlerin uzaktan eğitime olan öz yeterliğinin, $\mathrm{r}=.56, \mathrm{p}<.01$ uzaktan eğitime yönelik yarar algısı ile önemli ölçüde iliş̧kili olduğunu göstermiştir.

Aday öğretmenlerin uzaktan eğitime yönelik öz yeterlikleri için nispeten yüksek ortalama puanları, gelecekteki uzaktan eğitimciler olarak özellikle uzaktan eğitimin öğrenme, teknoloji ve sanal sınıf yönetimi yönlerinde kendilerini yetkin hissettiklerini ortaya koymuştur. Çalışma sonuçlarında, öz yeterlikleri kadar yüksek olmasa da, fayda algısı puanlarının iyiye oldukça yakın olduğu görülmektedir. Karatepe vd. (2020), 173 aday öğretmenle yaptığı çalışmada, aday öğretmenlerin uzaktan eğitimci olarak yetersiz hissettiklerini, yükseköğretim derslerinden edindikleri tecrübelere dayanarak uzaktan eğitime karșı olumsuz bir tutum sergilediklerini, ileride uzaktan eğitim vermek istemediklerini ortaya koymuştur. Bir başka çalışmada ise, 92 aday Türkçe öğretmeninin uzaktan eğitimi kullanma bilgi ve becerileri incelenmiş, katılımcıların \%50'sinin düşük düzeyde bilgi ve beceriye sahip olduğunu belirttiği bildirilmiştir (Karakuş vd., 2020). Söz konusu çalışmalar ile bu çalışma arasındaki çelişki, katılımcı aday öğretmenlerin lisans programları kapsamında tamamladıkları uzaktan eğitim dersinden ve dersin seçmeli niteliğinin aday öğretmenlerin yüksek puanlarına katkıda bulunmuş olabileceğinden kaynaklanıyor olabilir. Bu inançla, uzaktan eğitim dersinin başarılı ve başarısız yönlerini keşfetmenin lisans programları kapsamında gelecekte verilebilecek olan uzaktan eğitim derslerinin en iyi şekilde nasıl tasarlanabileceğine ışık tutabileceğini düşünülmüştür. Ayrıca, aday öğretmenlerin öz yeterliği ve algılanan fayda puanları arasındaki korelasyon analizi, teknoloji kabul modelini destekleyen, olumlu bir anlamlı korelasyona işaret etmektedir. Belirli bir teknolojinin kullanımına yönelik davranışsal niyeti neyin etkilediğine odaklanan model, algılanan yararılığın öz yeterlik de dahil olmak üzere dış değiş̧enlerden (Davis vd., 1989) etkilendiğini ve bu teknolojiyi kullanmak için davranışsal niyeti dolaylı olarak etkilediğini iddia etmektedir.

Öğretmen adaylarından açık uçlu anket yoluyla toplanan nitel verilerin analizi, dört olumlu sonuç temasını ortaya koymuştur: (1) Dersin, aday öğretmenlerin teknoloji entegrasyonu için bilgi ve beceri gelişimine katkısı; (2) Dersin, etkin bir uzaktan eğitim dersi tasarlamak için aday öğretmenlerin bilgi ve beceri gelişimine katkısı; (3) Dersin olumlu özellikleri ve (4) Genel olarak uzaktan eğitimin olumlu özellikleri. Katılımcı aday öğretmenlere Uzaktan Eğitim dersinin olumsuz yönlerini sorduğunda, 14'ü olumsuz bir hiçbir yön olmadığını belirtmiştir. Diğer katılımcıların cevapları analiz edildiğinde iki tema ortaya çıkmışıı: (1) Ortak ders bileşenleriyle ilgili problemler ve (2) Teknoloji ile ilgili problemler. Nitel sonuçlar tartışlarak teori ve uygulama için çıkarılabilecek sonuçlar ortaya konmuştur.

\section{ARAŞTIRMANIN ETIK IZNI}

Yapılan bu çalışmada "Yükseköğretim Kurumları Bilimsel Araştırma ve Yayın Etiği Yönergesi” kapsamında uyulması belirtilen tüm kurallara uyulmuştur. Yönergenin ikinci bölümü olan "Bilimsel Araştırma ve Yayın Etiğine Aykırı Eylemler" başlığı altında belirtilen eylemlerden hiçbiri gerçekleştirilmemiş̧ir.

\section{Etik kurul izin bilgileri}

Etik değerlendirmeyi yapan kurul adı: Bolu Abant İzzet Baysal Üniversitesi Sosyal Bilimlerde İnsan Araştırmaları Etik Kurulu

Etik değerlendirme kararının tarihi: 15.11.2020

Etik değerlendirme belgesi sayı numarası: 2020/260

\section{ARAŞTIRMACILARIN KATKI ORANI}

Araştırma tek yazarlı olduğu için yazarın katkısı \%100'dür.

\section{ÇATIŞMA BEYANI}

Araştırmada herhangi bir kişi ya da kurum ile finansal ya da kişisel yönden bağlantı bulunmamaktadır. 